\title{
Otopalatodigital syndrome type 1
}

INSERM

\section{Source}

INSERM. (1999). Orphanet: an online rare disease and orphan drug data base.

Otopalatodigital syndrome type 1. ORPHA:90650

Otopalatodigital syndrome type 1 (OPD1) is the mildest form of otopalatodigital syndrome spectrum disorder, and is characterized by a generalized skeletal dysplasia, mild intellectual disability, conductive hearing loss, and typical facial anomalies. 